Article

\title{
Analysis of Life Cycle Environmental Impact of Recycled Aggregate
}

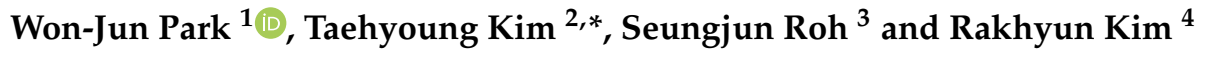 \\ 1 Department of Architectural Engineering, Kangwon National University, Sancheck, Kangwon-Do 25913, \\ Korea; wjpark@kangwon.ac.kr \\ 2 Department of Living and Built Environment Research, Korea Institute of Civil Engineering and Building \\ Technology, Goyang-Si, Gyeonggi-Do 10223, Korea \\ 3 School of Architecture, Kumoh National Institute of Technology, Gumi 39177, Korea; roh@kumoh.ac.kr \\ 4 Sustainable Building Research Center, Hanyang University, Ansan 15588, Korea; redwow6@hanyang.ac.kr \\ * Correspondence: kimtaehyoung@kict.re.kr; Tel.: +82-31-995-0838
}

Received: 31 December 2018; Accepted: 22 February 2019; Published: 12 March 2019

check for updates

\begin{abstract}
This study assessed the influence of matter discharged during the production (dry/wet) of recycled aggregate on global warming potential (GWP) and acidification potential (AP), eutrophication potential (EP), ozone depletion potential (ODP), biotic resource depletion potential (ADP), photochemical ozone creation potential (POCP) using the ISO 14044 (LCA) standard. The LCIA of dry recycled aggregate was $2.94 \times 10^{-2} \mathrm{~kg}-\mathrm{CO}_{2 \mathrm{eq}} / \mathrm{kg}, 2.93 \times 10^{-5} \mathrm{~kg}-\mathrm{SO}_{2 \mathrm{eq}} / \mathrm{kg}$,

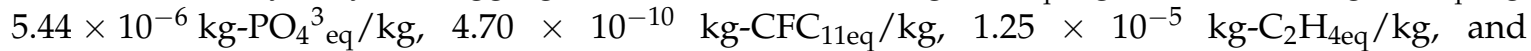
$1.60 \times 10^{-5} \mathrm{~kg}$-Antimonyeq $/ \mathrm{kg}$, respectively. The environmental impact of recycled aggregate (wet) was up to $16 \sim 40 \%$ higher compared with recycled aggregate (dry); the amount of energy used by impact crushers while producing wet recycled aggregate was the main cause for this result. The environmental impact of using recycled aggregate was found to be up to twice as high as that of using natural aggregate, largely due to the greater simplicity of production of natural aggregate requiring less energy. However, ADP was approximately 20 times higher in the use of natural aggregate because doing so depletes natural resources, whereas recycled aggregate is recycled from existing construction waste. Among the life cycle impacts assessment of recycled aggregate, GWP was lower than for artificial light-weight aggregate but greater than for slag aggregate.
\end{abstract}

Keywords: recycled aggregate; concrete; life cycle assessment; environmental impact

\section{Introduction}

In South Korea, redevelopment and reconstruction are being actively performed due to the economic and functional service-life expiry of older constructed structures. Such development inevitably generates a rapidly increasing quantity of construction waste. Waste concrete accounts for approximately $60 \%$ of the waste produced in redevelopment and reconstruction projects, and is not being effectively recycled despite attempts underway in countries such as the United States and Japan. Technology is currently under development to utilize recycled aggregate, obtained by crushing waste concrete, as a high-value-add material with applications such as aggregate for road construction and concrete. The field application of concrete using recycled aggregate is being performed with slowly increasing frequency in a variety of areas, including road construction.

The construction industry has been making efforts to become an economically and environmentally sustainable industry, while continuing to face social problems such as an increase in industrial and construction waste and the measures devised to process the waste cause further environmental problems, such as pollution and resource depletion [1]. 
Moreover, the use of natural aggregate is gradually decreasing due to changes in environmental awareness and the depletion of resources. The use of crushed stone aggregate and marine sand is increasingly replacing natural aggregate, but these materials also cause various problems, such as ecosystem destruction and transportation-distance challenges [2].

Recycled aggregates are alternative resources to river or forest aggregates. Their supply proportion is continuously increasing and will continue to play an important role as a recycled resource. If natural aggregates are consumed at the current level without promoting the usage of recycled aggregates at a rate of 30 million tons per year, all natural aggregates are expected to be exhausted in the next 20 years [3].

However, the process of producing recycled aggregate generates large environmental loads because it requires more processing than the collection of natural aggregate. In addition, the reliability of the quality of recycled aggregate is low, making it most suitable for utilization in landfill or embankments. Studies have been conducted on the quality of recycled aggregate, but there remains a paucity of research on the reduction of the environmental load generated by the production of recycled aggregate. Although the use of recycled aggregate that utilizes construction waste is being recognized as a positive phenomenon in terms of the efficient utilization of resources and the positive environmental aspects, minimizing the environmental loads inevitably generated by aggregate production remains an important issue.

Accordingly, a number of studies on the emissions and the reduction in the environmental impact of concretes that are mixed with recycled aggregates have been conducted overseas. A quantitative evaluation of concretes mixed with recycled and general aggregates is required to assess the various environmental impact categories (global warming potential (GWP), ozone depletion potential (ODP), photochemical ozone creation potential (POCP), eutrophication potential (EP), acidification potential (AP), and biotic resource depletion potential (ADP)).

This study assessed the life cycle environmental impact of recycled aggregate using life cycle assessment (LCA). It divided the process into raw materials, transport, and manufacturing of recycled aggregate, and identified the materials used in each stage and energy consumption amount in order to assess environmental impact. The study also compared and analyzed the environmental impact of recycled aggregate with artificial light-weight and slag aggregate.

\section{Literature Review}

Stefania Butera et al. [4] demonstrated that the utilization of construction and demolition waste in road construction as a replacement material for natural gravel was preferable to landfilling for most environmental-impact categories.

Laís Peixoto Rosado et al. [5] compared the natural and mixed recycled aggregate production for use as road base through a life cycle assessment. The primary data have been collected in a natural aggregate production facility and in a recycling facility of mixed aggregate in Southeast Brazil.

Vivian W. Y. Tam et al. [6] reviewed the literature on the production and utilization of recycled aggregate in concrete, concrete pavements, roadway construction, and other civil engineering works and some discussion on the savings on $\mathrm{CO}_{2}$ emissions have been included.

Md. Uzzal Hossain et al. [7] assessed the environmental impacts of aggregate production from these waste materials, and compared them with the aggregate production from virgin materials that can be utilized for the production of lower grade concrete products. Ardavan Yazdanbakhsh et al. [8] studied the influence of the choice of geographic boundaries on the results of regional LCA studies in a large and dense metropolitan area. Specifically, the study incorporates an LCA on the construction and demolition waste (CDW) produced, processed, and used in concrete.

Patrizia Ghisellini et al. [9] reviewed the recent literature within the framework of the circular economy to explore how its key principles (reduce, reuse, and recycle) apply to the management of construction and demolition waste. 
A. Julliena et al. [10] have assessed the energy consumption and impacts due to aggregate production within the LCA framework. Towards this end, a methodology has been presented that is specific to the impacts of aggregate production for various quarries.

Rawaz Kurda et al. [11] compared the environmental impacts of concrete mixes, which contain different incorporation ratios of fly ash and recycled concrete aggregates, with and without Superplasticizer. Mayuri Wijayasundara et al. [12] attempted to simulate the manufacturing set up to produce RAC by integrating processes involved in concrete waste recycling and concrete production environments.

S. Marinkovic et al. [13] determined the potentials of recycled aggregate concrete for structural applications and compared the environmental impact of the production of ready-mixed concrete: natural aggregate concrete made entirely with river aggregate and recycled aggregate concrete.

Rawaz Kurda et al. [14] mainly focused on the effect of high incorporation ratios of fly ash and recycled concrete aggregates on the carbonation resistance of concrete. Francesco Colangelo et al. [15] applied the standard protocol of LCA to three different concrete mixtures composed of wastes from construction and demolition, marble sludge, and cement kiln dust in order to compare the environmental and energy impacts.

Hossain, MU et al. [16] developed a social sustainability assessment tool based on the established standards and guidelines. The case study showed that four subcategories are crucial social concerns for construction materials. S.B.Marinković et al. [17] focused on the LCA of aggregates obtained by recycling of demolished concrete-recycled concrete aggregates, and concrete made with such aggregates-recycled aggregate concrete.

Desirée Rodríguez-Robles et al. [18] presented a literature review on expected environmental impacts inherent to the production and use of recycled aggregates and other common concrete constituents, as well as a LCA concerning some key issues when dealing with recycled aggregate concrete. Nikola Tošić et al. [19] determined the optimal choice of aggregate type and transport scenario in concrete production, employing a multicriteria optimization method taking into account technical, economic, and environmental limits and constraints.

Mayuri W. et al. [20] evaluated "cradle-to-gate" embodied energy of recycled concrete aggregate received at a construction site, in comparison to natural aggregate concrete. G.M. Cuenca-Moyano et al. [21] developed the life cycle inventory of masonry mortars made of natural fine aggregate and recycled fine aggregate. In order to create the inventory, the data used were those provided by producers [22].

Nicolas Serres et al. [23] evaluated environmental impacts associated with mixing compositions of concrete made of waste materials by using LCA. Environmental performances of natural formulation with the same mechanical strength regarding the functional unit, were evaluated.

Xin Shan et al. [24] presented LCA of a base case building in Singapore as well as material LCA with customized life cycle inventory datasets by considering importation and transportation of material in particular, and by considering the effects of adopting locally recycled aggregates.

F. Colangelo et al. investigate the physical and mechanical characteristics of different kind of construction and demolition waste obtained from selective and traditional demolition techniques [25].

\section{Analysis of Life Cycle Impact Assessment (LCIA)}

\subsection{Method}

This study assessed the environmental impact of recycled aggregate using LCA as defined by ISO standards. As environmental impact categories for life cycle impact assessment (LCIA), global warming, acidification, eutrophication, abiotic resource depletion, ozone layer destruction, and the production of photochemical oxides were chosen [26].

The functional unit for the life cycle impact assessment of recycled aggregate was $1 \mathrm{~kg}$, and the system boundary was product stage of concrete (Cradle to Gate) [27]. 
The production stage of recycled aggregate was divided into the raw material, transport, and manufacturing stage, and the environmental impact of all input and output matter on atmospheric and water systems was assessed for each stage [28]. The Life Cycle Index Database (LCI DB) of Korea was examined and applied as shown in Table 1 [29].

Table 1. The Life Cycle Index (LCI) Database.

\begin{tabular}{cccc}
\hline \multicolumn{2}{c}{ Division } & Reference & Country \\
\hline \multirow{2}{*}{ Raw material } & Waste concrete & National LCI & Korea \\
\hline \multirow{2}{*}{ Energy } & Electric & National LCI & Korea \\
& Diesel & National LCI & Korea \\
& Kerosene & National LCI & Korea \\
\hline \multirow{2}{*}{ Transportation } & Truck & National LCI & Korea \\
\hline
\end{tabular}

\subsection{Process of LCIA}

Life cycle impact assessment is divided into the following [30,31]: classification, which collects substances drawn from inventory analysis into their relevant environmental impact categories; characterization, which quantifies the impact of items classified as environmental impact categories; normalization, which divides the impact on environmental impact categories by the total environmental impact of a certain region or period; and weighting which determines the relative importance of impact categories [32]. This study assessed all stages up to characterization since the normalization and weighting factors of recycled aggregates that fit the current situation of Korea have not been developed $[33,34]$.

The substances discharged from recycled aggregate production impact the atmosphere and water quality, and the resulting environmental issues include global warming potential (GWP), ozone depletion potential (ODP), photo-chemical oxidant creation potential (POCP), abiotic depletion potential (ADP), eutrophication potential (EP), and acidification potential (AP) [35].

$$
\mathrm{CI}_{\mathrm{i}}=\sum \mathrm{CI}_{\mathrm{i}, \mathrm{j}}=\sum\left(\operatorname{Load}_{\mathrm{j}} \times \mathrm{eqv}_{\mathrm{i}, \mathrm{j}}\right)
$$

Here, $\mathrm{CI}_{\mathrm{i}}$ is the value of the impact by all inventory items (j) included in impact category $i$ in the belonging impact categories; $\mathrm{CI}_{\mathrm{i}, \mathrm{j}}$ is the impact size by inventory item $\mathrm{j}$ on impact category $\mathrm{i}$; Load $_{j}$ is the environmental load of inventory item $j$; and eqvi,j is the characterization coefficient value of inventory item $\mathrm{j}$ in impact category $\mathrm{i}$.

\subsubsection{Raw Material Stage}

This study assessed the environmental impact according to the production process of waste concrete, a raw material for recycled aggregate [36]. Recycling breaks and separates waste concrete into small pieces and recycled aggregate are produced for use. Waste concrete is generated during the demolition and deconstruction of structures and is classified as construction waste if it is not used as another product. During the deconstruction of a building, a large amount of energy is used and environmental impact substances are discharged; however, since waste concrete is a by-product, its previous industrial process is not included in the environmental impact assessment category. Thus, the process of waste concrete discharge during the demolition and deconstruction of a structure was excluded from the categories of environmental impact assessment.

$$
\text { Raw material }_{\mathrm{E} . \mathrm{I}}=\sum[(\mathrm{M}(\mathrm{i}) / \mathrm{Wc}) \times \mathrm{t} \times \mathrm{D}](\mathrm{i}=\text { Waste concrete })
$$

Here, raw material E.I is the environmental impact of raw materials, (kg-unit $/ \mathrm{kg}), \mathrm{M}(\mathrm{i})$ is waste concrete (ton), Wc is (i) the volume (ton) of waste concrete collecting equipment, T is work hours (h), and $\mathrm{D}$ is characterization value (kg-unit/L) of diesel by environmental impact category. 


\subsubsection{Transportation Stage}

The waste concrete collected from the building demolition/deconstruction sites was transported to a recycled aggregate production factory by truck, and the transport distance was $30 \mathrm{~km}$ on average. From the loading capacity of transportation means and the amount of waste concrete, the number of transport equipment units was calculated and transport was applied to assess environmental impact.

$$
\text { Transportation }_{\text {E.I }}=\sum[(\mathrm{M}(\mathrm{i}) / \mathrm{Wt}) \times \mathrm{d} \times \mathrm{D}](\mathrm{i}=\text { Waste concrete })
$$

Here, Transportation E.I is transport stage environmental impact (kg-unit/kg), $\mathrm{M}_{(\mathrm{i})}$ is waste concrete (ton), $\mathrm{Wt}$ is the loading amount (ton) of (i) transport equipment, $\mathrm{d}$ is transport distance $(\mathrm{km})$, and $\mathrm{D}$ is the characterization value of crude oil by environmental impact categories (kg-unit/L).

\subsubsection{Manufacturing Stage}

In this stage, waste concrete is selected and crushed to manufacture recycled aggregate [37]. The manufacturing method can be divided into the dry method and the wet method. To assess the environmental impact of each manufacturing method, the amount of electric power used in the manufacturing facility was examined and the environmental impact according to the usage of the energy source was assessed.

$$
\text { Manufacture }_{\mathrm{E} . \mathrm{I}}=\sum\left[\left(\mathrm{E}_{(\mathrm{i})} / \mathrm{W}_{\mathrm{a}}\right) \times \mathrm{C}\right](\mathrm{i}=1 \text { : Electric })
$$

Here, Manufacture E.I is environmental impact (kg-unit $/ \mathrm{kg}$ ) in the manufacturing stage, $\mathrm{W}_{\mathrm{a}}$ is the amount of recycled aggregate production $(\mathrm{kg}), \mathrm{E}_{(\mathrm{i})}$ is the amount of energy source use (kwh), and $\mathrm{C}$ is characterization value (kg-unit/kwh) of electric power by environmental impact categories.

\section{Dry Method}

The dry production method uses a technology that eliminates mortar on an aggregate surface by crushing waste concrete and easily separates a fair amount of fine powder generated to produce high-quality recycled aggregate as shown in Table 2. The number of crushing and differentiation work taken during the production process was divided for each equipment and shown in Figure 1. The environmental impact emission amount by electric power usage for each equipment unit was calculated for the process of producing recycled aggregate through the dry production method.

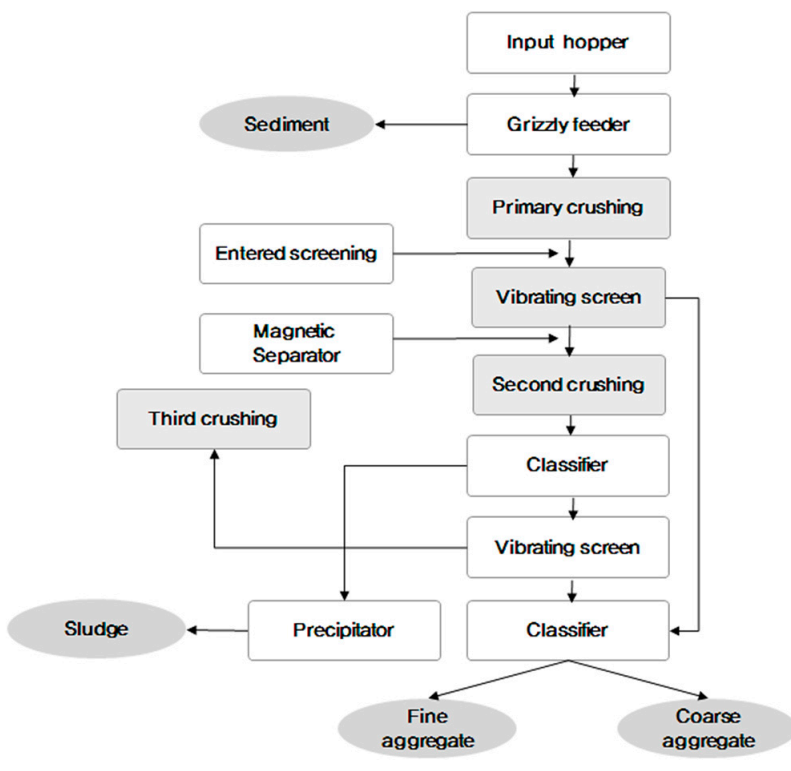

Figure 1. Dry production method. 
Table 2. Manufacturing facility of dry recycled aggregate.

\begin{tabular}{cccc}
\hline & Dry System & Operation Count & Total Electricity Usage \\
\hline \multirow{2}{*}{ Feeders } & Grizzly feeder & 1 time & $183.33 \mathrm{~kW}$ \\
\hline \multirow{2}{*}{ Screen } & Vibrating screen & 4 times & $169.01 \mathrm{~kW}$ \\
\hline \multirow{2}{*}{ Crusher } & Jaw Crusher & 1 time & $593.75 \mathrm{~kW}$ \\
\cline { 2 - 4 } & Cone Crusher & 3 times & $529.41 \mathrm{~kW}$ \\
\hline \multicolumn{2}{c}{ Magnetic Separator } & 1 time & $250.00 \mathrm{~kW}$ \\
\hline \multicolumn{2}{c}{ Classifier } & 3 times & $289.47 \mathrm{~kW}$ \\
\hline & Precipitator & 1 time & $750.00 \mathrm{~kW}$ \\
\hline
\end{tabular}

This study assumed that the production efficiency of aggregate was $70 \%$ and set that cone and jaw crushers were used twice to produce high-quality recycled aggregate.

\section{Wet Method}

The wet production method includes a selection process that is not included in the dry production method. It has an air blower as a selection device in the middle, and, unlike the dry production method in which two types of crushers are applied, the wet production method uses only an impact crusher. The wet production system needs significant initial cost and vast land since facilities such as cleaning, precipitation, and filter presses are needed. Due to the issue of reclaiming sludge cake generated from production instead of recycling it, this method also has many difficulties in recycled sand production.

However, the wet system can more easily produce high-quality recycled sand compared with the dry system; aggregates have good particle size and form, and the process is favorable for high volume production, so the wet system using water has been applied in Korea. The number of crushing and differentiation work taken in the production process by equipment was classified by equipment type in Figure 2. This study assumed the production efficiency of aggregate was $70 \%$ and assumed that crushing was carried out by using a cone crusher twice and a jaw crusher once to produce quality aggregate as shown in Table 3.

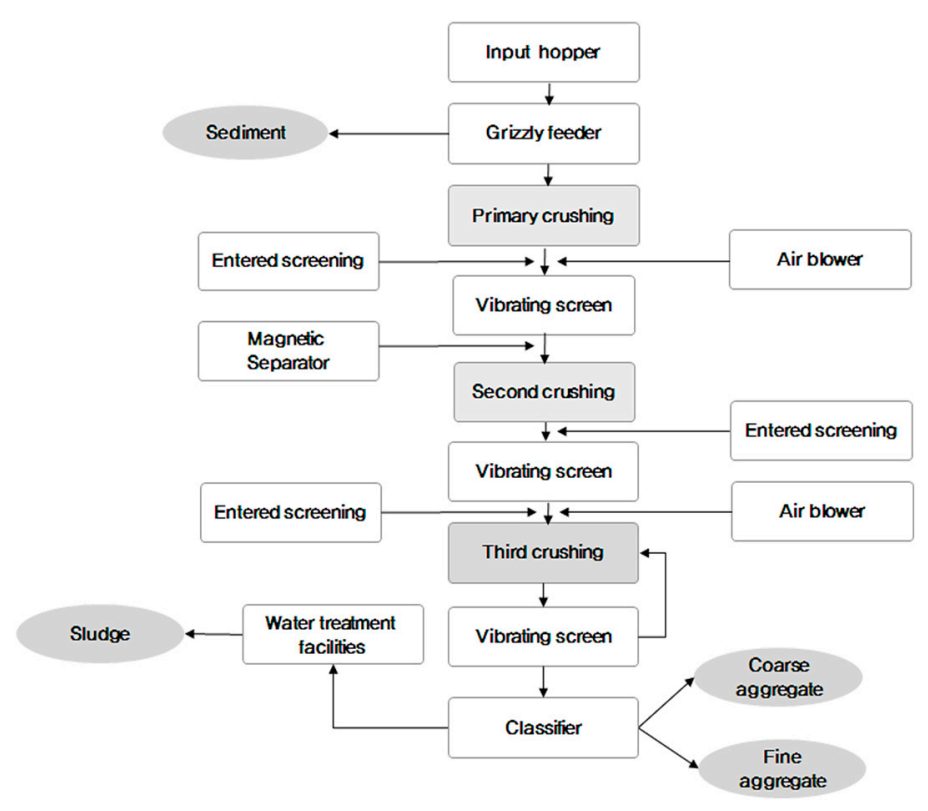

Figure 2. Wet production method process. 
Table 3. Manufacturing facility for wet recycled aggregate.

\begin{tabular}{cccc}
\hline \multicolumn{2}{c}{ Dry System } & Operation Count & Total Electricity Usage \\
\hline \multirow{2}{*}{ Feeders } & Grizzly feeder & 1 time & $315.79 \mathrm{~kW}$ \\
\hline \multirow{2}{*}{ Screen } & Vibrating screen & 3 times & $240.00 \mathrm{~kW}$ \\
\cline { 2 - 4 } Crusher & Jaw crusher & 1 time & $600.00 \mathrm{~kW}$ \\
\cline { 2 - 4 } & Cone crusher & 1 time & $450.00 \mathrm{~kW}$ \\
\cline { 2 - 4 } & Impact crusher & 1 time & $950.00 \mathrm{~kW}$ \\
\hline \multicolumn{2}{c}{ Air blower } & 2 times & $840.00 \mathrm{~kW}$ \\
\hline \multicolumn{2}{c}{ Magnetic Separator } & 3 times & $120.00 \mathrm{~kW}$ \\
\hline
\end{tabular}

\subsection{Result of LCIA}

The life cycle impact assessment (LCIA) of recycled aggregate (dry) was $2.94 \times 10^{-2} \mathrm{~kg}-\mathrm{CO}_{2 \mathrm{eq}} / \mathrm{kg}$, $2.93 \times 10^{-5} \mathrm{~kg}-\mathrm{SO}_{2 \mathrm{eq}} / \mathrm{kg}, 5.44 \times 10^{-6} \mathrm{~kg}-\mathrm{PO}_{4}{ }^{3} \mathrm{eq} / \mathrm{kg}, 4.70 \times 10^{-10} \mathrm{~kg}-\mathrm{CFC}_{11 \text { eq }} / \mathrm{kg}, 1.25 \times 10^{-5}$ $\mathrm{kg}-\mathrm{C}_{2} \mathrm{H}_{4 \mathrm{eq}} / \mathrm{kg}$, and $1.60 \times 10^{-5} \mathrm{~kg}$-Antimony ${ }_{\mathrm{eq}} / \mathrm{kg}$ for GWP, AP, EP, ODP, POCP, and ADP, respectively, as shown in Table 4.

Table 4. Life cycle impact assessment of recycled aggregate; GWP: Global Warming Potential; ADP: Abiotic Depletion Potential; ODP: Ozone Depletion Potential; AP: Acidification Potential; EP: Eutrophication Potential; POCP: Photochemical Ozone Creation Potential.

\begin{tabular}{|c|c|c|c|c|c|c|c|}
\hline \multicolumn{2}{|c|}{ Division } & $\begin{array}{c}\mathrm{GWP} \\
\left(\mathrm{kg}-\mathrm{CO}_{2 \mathrm{eq}} / \mathrm{kg}\right)\end{array}$ & $\begin{array}{c}\mathrm{AP} \\
\left(\mathrm{kg}-\mathrm{SO}_{2 \mathrm{eq}} / \mathrm{kg}\right)\end{array}$ & $\begin{array}{c}\mathrm{EP} \\
\left(\mathrm{kg}-\mathrm{PO}_{4}{ }^{3-}{ }_{\text {eq }} / \mathrm{kg}\right)\end{array}$ & $\begin{array}{c}\text { ODP } \\
\left(\mathrm{kg}-\mathrm{CFC11}_{\mathrm{eq}} / \mathrm{kg}\right)\end{array}$ & $\begin{array}{c}\text { POCP } \\
\left(\mathrm{kg}-\mathrm{C}_{2} \mathrm{H}_{4} \text { eq } / \mathrm{kg}\right)\end{array}$ & $\begin{array}{c}\text { ADP } \\
\left.\text { (kg-Antimony }_{\text {eq }} / \mathrm{kg}\right)\end{array}$ \\
\hline \multicolumn{2}{|c|}{ Raw material stage } & $3.10 \times 10^{-3}$ & $3.90 \times 10^{-6}$ & $7.90 \times 10^{-7}$ & $3.00 \times 10^{-11}$ & $8.30 \times 10^{-6}$ & $1.00 \times 10^{-6}$ \\
\hline \multirow{2}{*}{$\begin{array}{l}\text { Manufacture } \\
\text { stage }\end{array}$} & Dry & $2.23 \times 10^{-2}$ & $1.79 \times 10^{-5}$ & $3.57 \times 10^{-6}$ & $3.70 \times 10^{-10}$ & $3.10 \times 10^{-6}$ & $2.00 \times 10^{-6}$ \\
\hline & Wet & $3.10 \times 10^{-2}$ & $2.99 \times 10^{-5}$ & $4.46 \times 10^{-6}$ & $4.80 \times 10^{-10}$ & $5.90 \times 10^{-6}$ & $7.00 \times 10^{-6}$ \\
\hline
\end{tabular}

LCIA of recycled aggregate (wet) was $3.81 \times 10^{-2} \mathrm{~kg}-\mathrm{CO}_{2 \mathrm{eq}} / \mathrm{kg}, 4.13 \times 10^{-5} \mathrm{~kg}-\mathrm{SO}_{2 \mathrm{eq}} / \mathrm{kg}$, $6.33 \times 10^{-6} \mathrm{~kg}^{-\mathrm{PO}_{4}}{ }^{3}$ eq $/ \mathrm{kg}, 5.80 \times 10^{-10} \mathrm{~kg}-\mathrm{CFC}_{11 \mathrm{eq}} / \mathrm{kg}, 1.53 \times 10^{-5} \mathrm{~kg}-\mathrm{C}_{2} \mathrm{H}_{4 \mathrm{eq}} / \mathrm{kg}$, and $2.10 \times 10^{-5}$ $\mathrm{kg}$-Antimony eq $/ \mathrm{kg}$ for GWP, AP, EP, ODP, POCP, and ADP, respectively.

This shows that the LCIA of recycled aggregate (wet) was greater than that of recycled aggregate (dry), and that GWP and ADP of recycled aggregate (wet) were 30\% higher than for recycled aggregate (dry). ODP and POCP were also greater by $20 \%$ and AP was greater by $40 \%$. EP showed a difference of about $16 \%$, because it was determined according to the electric power of the additional facility (impact crusher) used for producing recycled aggregate (wet). This was because more carbon dioxide $\left(\mathrm{CO}_{2}\right)$, trichlorofluoromethane (CFC-11), chlorodifluoromethane (HCFC-22), phosphate $\left(\mathrm{PO}_{4}{ }^{3-}\right)$, crude oil, ammonia $\left(\mathrm{NH}_{3}\right)$, nitrogen oxides (NOx), and ethylene $\left(\mathrm{C}_{2} \mathrm{H}_{4 \mathrm{eq}}\right)$, which impact the environment as more electric power was consumed, were directly and indirectly released.

Among environmental impact categories, the manufacturing stage of the life cycle constituted approximately $81 \%, 72 \%, 70 \%$, and $83 \%$ of GWP, AP, EP, and ODP, respectively.

However, the raw material stage was responsible for the highest proportion of POCP at $66 \%$ and the transportation stage for $81 \%$ of ADP. 


\section{Comparison of Life Cycle Impact Assessment}

\subsection{Method}

The LCIA results for recycled aggregate were compared with those for natural aggregate and artificial light-weight aggregate, slag aggregate. Previous studies were referred to for the LCIA results of natural aggregate and artificial light-weight aggregate, slag aggregate.

\subsection{Information on Other Aggregates}

\subsubsection{Natural Aggregate}

Natural aggregate is made by natural actions, and includes both sand and gravel sourced from sea, land, and mountains. This study focused on gravel. Gravel is collected and classified in plants by size $(25 \mathrm{~m}, 45 \mathrm{~m}$, or $75 \mathrm{~m})$ for later application, and is mainly used as aggregate for concrete or filler for roads and septic tanks.

\subsubsection{Artificial Light-Weight Aggregate}

First, an artificial light-weight aggregate is manufactured by processing coal material (bottom ash), shale, and clay generated from coal powerplants and through plastic bulging (firing), to obtain required physical characteristics [38].

Artificial light-weight aggregate is produced through the mixing, crushing, molding, and plastic process of bottom ash for dry coal material, and the material satisfies wide-ranging functions required in the complex construction field such as light-weight characteristics, insulation, sound absorption, and thermal resistance.

Dredged soil and bottom ash are the main ingredients of artificial light-weight aggregate; energy such as electricity, LPG, and coal are used for manufacturing.

\subsubsection{Slag Aggregate}

Steel slag is largely divided into shaft slag and hard steel slag depending on the production process, and it is $100 \%$ recycled according to the current statistics [39].

Shaft slag, which is recycled more than $75 \%$ as the raw material for cement, is used as a relatively high-value addition. However, since most hard steel slag is used as a low-value addition for roads and fill-up, development of value-added technology is needed.

Slag aggregate is produced by watering and cooling the shaft of hard steel slag in an open-air storage yard and through quarrying and crushing processes. During quarrying and crushing, energy such as electricity, oil, and water are used.

Slag aggregate, which uses slag as the main raw ingredient, is used for various purposes such as roads and ceramics and is mostly used for civil construction.

\subsection{Comparison of Environmental Impact by Aggregate Type}

As shown in Table 5, the environmental impact of recycled aggregate was compared with that of natural aggregate and artificial light-weight aggregate, slag aggregate. 
Table 5. Environmental impact comparison by aggregate type.

\begin{tabular}{|c|c|c|c|c|c|c|c|}
\hline \multicolumn{2}{|c|}{ Division } & $\begin{array}{c}\mathrm{GWP} \\
\left(\mathrm{kg}-\mathrm{CO}_{2 \mathrm{eq}} / \mathrm{m}^{3}\right)\end{array}$ & $\begin{array}{c}\mathrm{AP} \\
\left(\mathrm{kg}-\mathrm{SO}_{2 \mathrm{eq}} / \mathrm{m}^{3}\right)\end{array}$ & $\begin{array}{c}\mathrm{EP} \\
\left(\mathrm{kg}-\mathrm{PO}_{4}{ }^{3-}{ }_{\mathrm{eq}} / \mathrm{m}^{3}\right)\end{array}$ & $\begin{array}{c}\text { ODP } \\
\left(\mathrm{kg}-\mathrm{CFC11}_{\mathrm{eq}} / \mathrm{m}^{3}\right)\end{array}$ & $\begin{array}{c}\text { POCP } \\
\left(\mathrm{kg}-\mathrm{C}_{2} \mathrm{H}_{4 \mathrm{eq}} / \mathrm{m}^{3}\right)\end{array}$ & $\begin{array}{c}\text { ADP } \\
\left.\text { (kg-Antimony }{ }_{\mathrm{eq}} / \mathrm{m}^{3}\right)\end{array}$ \\
\hline \multirow{2}{*}{$\begin{array}{l}\text { Recycled } \\
\text { aggregate }\end{array}$} & Dry & $2.94 \times 10^{-2}$ & $2.93 \times 10^{-5}$ & $5.44 \times 10^{-6}$ & $4.68 \times 10^{-10}$ & $1.25 \times 10^{-5}$ & $1.60 \times 10^{-5}$ \\
\hline & Wet & $3.81 \times 10^{-2}$ & $4.13 \times 10^{-5}$ & $6.33 \times 10^{-6}$ & $5.80 \times 10^{-10}$ & $1.53 \times 10^{-5}$ & $2.10 \times 10^{-5}$ \\
\hline \multicolumn{2}{|c|}{$\begin{array}{l}\text { Artificial } \\
\text { Lightweight } \\
\text { aggregate }\end{array}$} & $5.16 \times 10^{-2}$ & $1.73 \times 10^{-4}$ & $2.80 \times 10^{-5}$ & $4.01 \times 10^{-9}$ & $5.28 \times 10^{-5}$ & $1.94 \times 10^{-4}$ \\
\hline
\end{tabular}

According to Figure 3, the environmental impact of recycled aggregate was found to be up to twice as high as that of natural aggregate. Compared to natural aggregate, the global warming potential (GWP) was approximately $106 \%$ (dry) and $166 \%$ (wet) higher, AP was $48 \%$ (dry) and $109 \%$ (wet) higher, EP was $48 \%$ (dry) and $72 \%$ (wet) higher, and ODP was 53\% (dry) and 90\% (wet) higher for recycled aggregate. The manufacturing process for natural aggregate consumes very little energy because it involves simple processes, such as collection, transportation, and (minimal) processing.

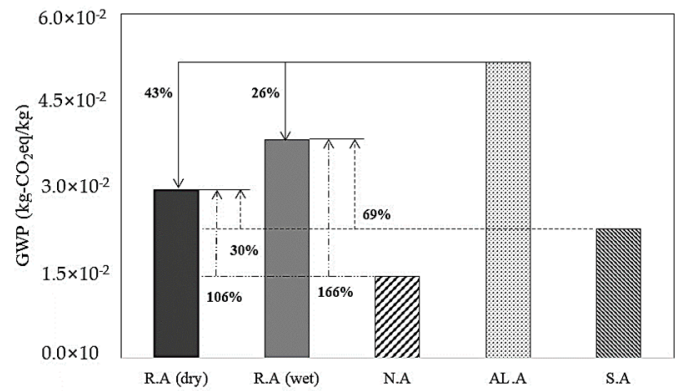

(a)

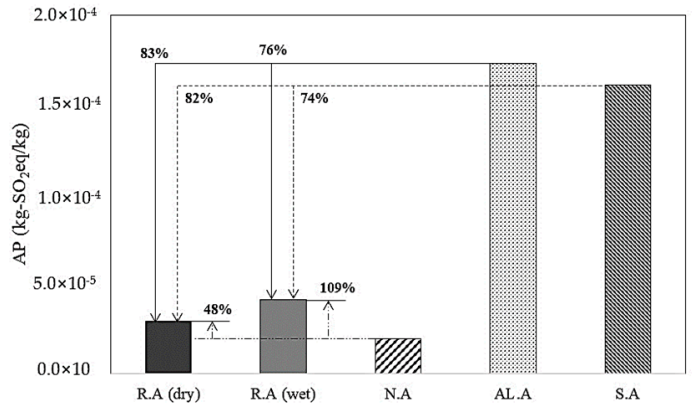

(c)

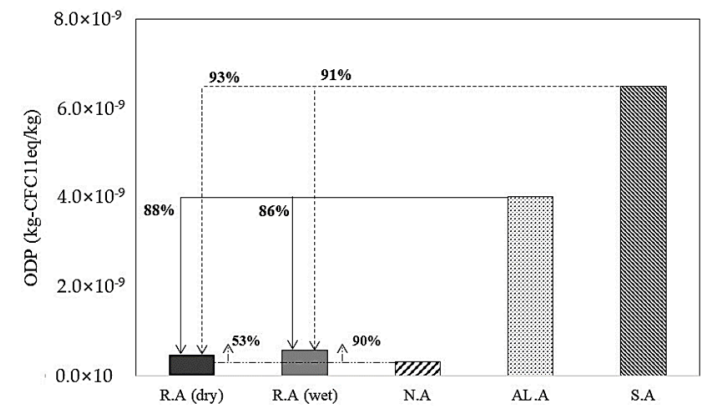

(e)

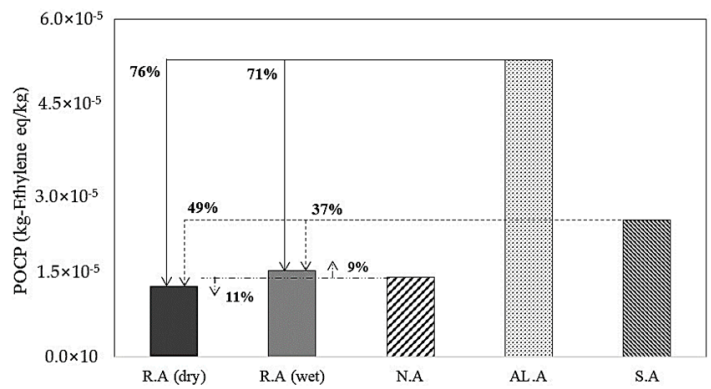

(b)

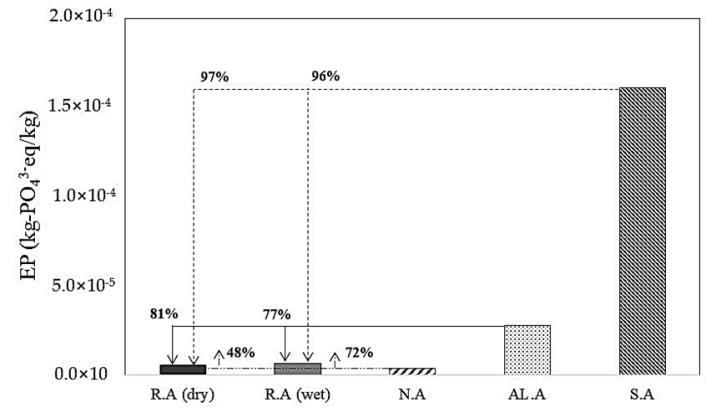

(d)

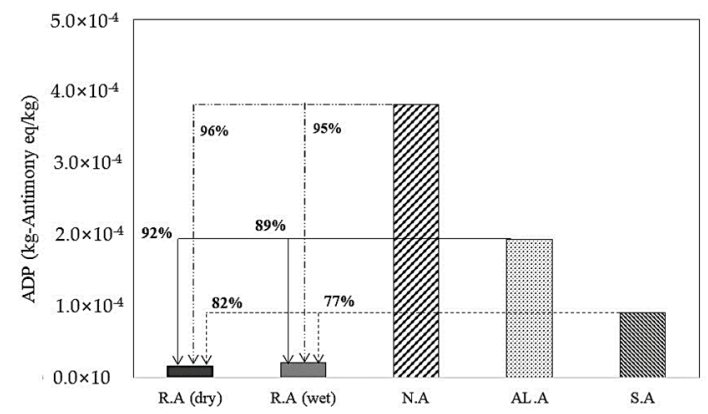

(f)

Figure 3. Environmental impact comparison by aggregate. (a) GWP: Global Warming Potential; (b) POCP: Photochemical Ozone Creation Potential; (c) AP: Acidification Potential; (d) EP: Eutrophication Potential; (e) ODP: Ozone Depletion Potential; (f) ADP: Abiotic Depletion Potential 
Recycled aggregate, on the other hand, requires a lot of energy for physical and chemical processes, such as crushing, sorting, transportation, processing, and particle adjustment. However, the abiotic depletion potential (ADP), an important environmental impact measure, was found to be approximately 20 times higher for natural aggregate than for recycled aggregate. This is because the recycled aggregate is simply recycled construction waste, but natural aggregate depletes natural resources. Among environmental impacts emitted during recycled aggregate production GWP was $43 \%$ (dry) and 26\% (wet) lower than for artificial light-weight aggregate, but was 30\% (dry) and 69\% (wet) greater than for slag aggregate.

This is because the amount of energy used, such as electricity, LNG (liquid natural gas), and coal in the mixing, molding, and plasticity processes, during artificial light-weight aggregate production was higher than the amount of energy used by recycled aggregate. This was due to the high emissions of $\mathrm{CO}_{2}, \mathrm{CH}_{4}$, and $\mathrm{N}_{2} \mathrm{O}$, which are the main compounds impacting GWP. At the same time, the amount of energy used in the differentiation and crushing processes during recycled aggregate production was higher than the amount of energy used by slag aggregate. AP, EP, ODP, POCP, and ADP also impact according to the emissions during recycled aggregate production were assessed to be lower by $37 \%$ to 93\% compared with artificial light-weight aggregate and slag aggregate.

This is because $\mathrm{NOx}, \mathrm{NH}_{3}, \mathrm{SO}_{2}, \mathrm{NH}_{4}$, Halon, CFCs (Chlorofluorocarbons), soft coal, hard coal, and crude oil that impact AP, EP, ODP, POCP, and ADP during recycled aggregate production were emitted less than during artificial light-weight aggregate and slag aggregate production.

Due to the use of LNG and coal energy during the manufacturing of lightweight aggregate and slag aggregate, matters that impact acidification, eutrophication, and ozone depletion, such as sulfur dioxide $\left(\mathrm{SO}_{2}\right)$, sulfuric acid $\left(\mathrm{H}_{2} \mathrm{SO}_{4}\right)$, and nitrate $\left(\mathrm{NO}_{3}{ }^{-}\right)$are emitted. Ammonia $\left(\mathrm{NH}_{3}\right)$, ammonium $\left(\mathrm{NH}_{4}{ }^{+}\right)$, phosphate $\left(\mathrm{PO}_{4}{ }^{3-}\right)$, nitrogen oxide (NOx), etc., according to electric energy usage are emitted as well. This is because matters impacting the environment are emitted when coal input in thermoelectric powerplant is combusted to produce electric energy.

Especially, the ADP of recycled aggregate was lower by $77 \%$ to $92 \%$ compared with artificial light-weight aggregate and slag aggregate. This is because recycled aggregate uses industrial by-products as raw materials, a small amount of ADP's main impact matters such as iron (Fe), natural gas, hard coal, lead $(\mathrm{Pb})$, and uranium $(\mathrm{U})$ were emitted.

\section{Discussion}

Recently, the application of recycled aggregate has been expanded to major concrete structure elements, such as the columns and beams of construction structures. For concrete, the major material used in the construction industry, environmental impact analysis is required because it discharges many substances with a high environmental load over its life cycle from production to construction, maintenance, and destruction/disposal. Concrete is a mixture of cement, aggregate, and admixture. Cement production consumes a large amount of energy during the processes of extracting limestone and clay and manufacturing clinker. Moreover, soil erosion or ecosystem destruction may occur in the process of collecting the necessary aggregate. Energy is also consumed in the course of transporting materials, such as cement and aggregate, to concrete manufacturers, and when producing concrete in batch plants, various high-environmental-load substances are discharged into the air, water, and soil.

As the concrete production process impacts the environment in a variety of ways, it was necessary to assess various environmental impact categories as shown Figure 4. First, for concrete with a compressive strength of $24 \mathrm{MPa}$, a life cycle assessment was performed according to the volume fraction (substitution rate) of recycled aggregate (R.G) used instead of natural aggregate. As the volume fraction increased, GWP, one of the environmental impact categories, increased by $11-34 \%$ compared to when only using natural aggregate. This is because $\mathrm{CO}_{2}, \mathrm{CH}_{4}$, and $\mathrm{N}_{2} \mathrm{O}$ emissions, which all have a major effect on GWP, are larger during the production of recycled aggregate than during the production of natural aggregate. As the volume fraction of recycled aggregate increased to $10 \%, 20 \%$, and $30 \%$, the ADP decreased by $9-29 \%$ compared to the ADP of the concrete with natural aggregate 
only. This is because antimony (Sb), hard coal, and crude oil emissions, which affect ADP, were smaller during the production of recycled aggregate than during the production of natural aggregate.

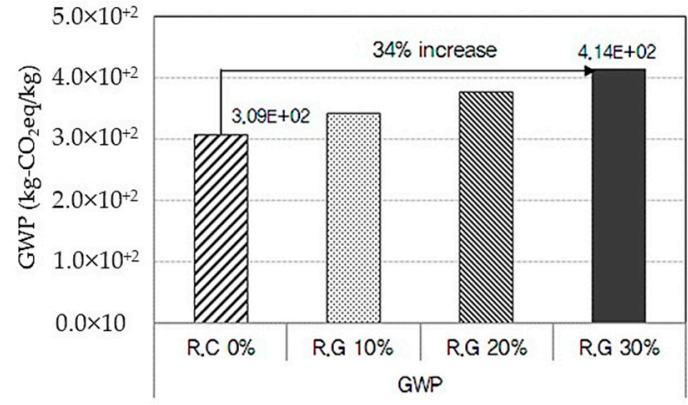

(a)

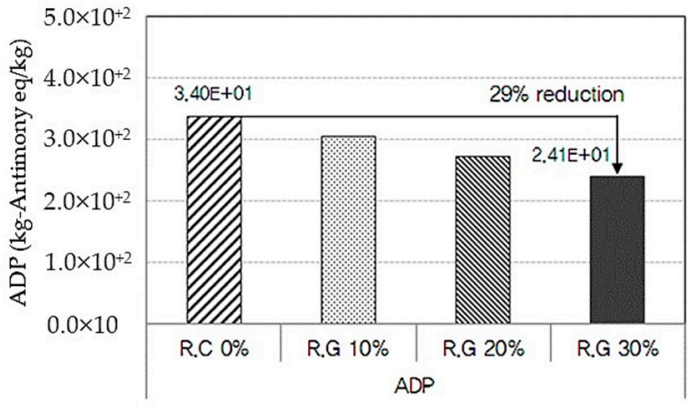

(b)

Figure 4. Comparison of environmental impact by recycled aggregate mixing ratio. (a) GWP: Global Warming Potential; (b) ADP: Abiotic Depletion Potential

\section{Conclusions}

By observing the ISO 14044 (LCA) standard, this study assessed the life cycle environmental impact of matter discharged in the production (dry/wet) of recycled aggregate on GWP, AP, EP, ODP, $\mathrm{ADP}$, and POCP.

The environmental impact of recycled aggregate (wet) was up to $16 \%(\mathrm{EP}) \sim 40 \%(\mathrm{AP})$ higher compared with recycled aggregate (dry); the amount of energy used by impact crushers while producing wet recycled aggregate was the main cause for this result.

Comparing the methods of production, while the environmental impact of the recycled aggregate produced by the wet method is somewhat high, the wet method remains the most practical method, and is beneficial in terms of the aggregate quality attained due to the high fine-powder-removal effect achieved by washing with water. The recycled aggregate produced by the dry method has a simpler production process and a lower production cost, but its quality requires improvement because the impurity and adhesive mortar removal efficiency is low.

The environmental impact of using recycled aggregate was found to be up to twice as high as that of using natural aggregate, largely due to the greater simplicity of production of natural aggregate requiring less energy. However, ADP was approximately 20 times higher in the use of natural aggregate because doing so depletes natural resources, whereas recycled aggregate is recycled from existing construction waste.

Among the life cycle impacts assessment of recycled aggregate, GWP was lower than for artificial light-weight aggregate but greater than for slag aggregate. This is because energy use, such as electricity, LNG, and coal in the mixing, molding, and frit sealing process during the production of artificial light-weight aggregate was higher than the amount of energy used in the production of recycled aggregate. However, in the environmental impact of recycled aggregate, AP, EP, ODP, POCP, and ADP were lower by $37 \%$ to $93 \%$ than that of artificial light-weight aggregate and slag aggregate. Although the concrete into which recycled aggregate was substituted exhibited a somewhat higher environmental impact than natural aggregate in terms of GWP, it was found to be more environmentally friendly in terms of ADP.

The results drawn through this study do not represent the environmental impact index of all recycled aggregates, and the range of environmental impact indices must be assessed through more analyses in the future.

Author Contributions: Author contributions for this research article are as follows; conceptualization, W.-J.P.; methodology and investigation, S.-J.R.; data curation, R.-H.K.; writing—original draft preparation, T.-H.K.; writing and editing, W.-J.P.; review and editing, T.-H.K. 
Funding: This work was supported by both a grant (19CTAP-C141186-02) from Technology Advancement Research Program (TARP) funded by Ministry of Land, Infrastructure and Transport of Korean Government and the National Research Foundation of Korea (NRF) grant (No. NRF-2018R1D1A3B07045700) funded by the Korea government.

Conflicts of Interest: The authors declare no conflict of interest.

\section{References}

1. Ministry of the Interior. Law of Low-Carbon on Green Growth; Ministry of Government Legislation: Sejong-si, Korea, 2013.

2. Department of Climate Policy. Climate Change Handbook, Korea Meteorological Administration; Korea Meteorological Administration: Seoul, Korea, 2009.

3. Ministry of Environment. Waste Recycling: Extended Producer Responsibility; Ministry of Environment: Sejong-si, Korea, 2012.

4. Butera, S.; Christensen, T.H.; Astrup, T.F. Life cycle assessment of construction and demolition waste management. Waste Manag. 2015, 44, 196-205. [CrossRef] [PubMed]

5. Rosado, L.P.; Vitale Penteado, C.S.G.; Arena, U. Life cycle assessment of natural and mixed recycled aggregate production in Brazil. J. Clean. Prod. 2017, 151, 634-642. [CrossRef]

6. Tam, V.W.Y.; Soomro, M.; Evangelista, A.C.J. A review of recycled aggregate in concrete applications (2000-2017). Constr. Build. Mater. 2018, 172, 272-292. [CrossRef]

7. Hossain, M.U.; Poon, C.S.; Lo, I.M.C.; Cheng, J.C.P. Comparative environmental evaluation of aggregate production from recycled waste materials and virgin sources by LCA. Resour. Conserv. Recycl. 2016, 109, 67-77. [CrossRef]

8. Yazdanbakhsh, A.; Lagouin, M. The effect of geographic boundaries on the results of a regional life cycle assessment of using recycled aggregate in concrete. Resour. Conserv. Recycl. 2019, 143, 201-209. [CrossRef]

9. Ghisellini, P.; Ripa, M.; Ulgiati, S. Exploring environmental and economic costs and benefits of a circular economy approach to the construction and demolition sector. J. Clean. Prod. 2018, 178, 618-643. [CrossRef]

10. Julliena, A.; Proust, C.; Martaud, T.; Rayssac, E.; Ropert, C. Variability in the environmental impacts of aggregate production. Resour. Conserv. Recycl. 2012, 62, 1-13. [CrossRef]

11. Kurda, R.; Silvestre, J.D.; de Brito, J. Life cycle assessment of concrete made with high volume of recycled concrete aggregates and fly ash. Resour. Conserv. Recycl. 2018, 139, 407-417. [CrossRef]

12. Wijayasundara, M.; Mendis, P.; Zhang, L.; Sofi, M. Financial assessment of manufacturing recycled aggregate concrete in ready-mix concrete plants. Resour. Conserv. Recycl. 2016, 109, 187-201. [CrossRef]

13. Marinkovic, S.; Radonjanin, V.; Malešev, M.; Ignjatovic, I. Comparative environmental assessment of natural and recycled aggregate concrete. Waste Manag. 2010, 30, 2255-2264. [CrossRef]

14. Kurda, R.; de Brito, J.; Silvestre, J.D. Carbonation of concrete made with high amount of fly ash and recycled concrete aggregates for utilization of $\mathrm{CO}_{2}$. J. CO2 Util. 2019, 29, 12-19. [CrossRef]

15. Colangelo, F.; Petrillo, A.; Cioffi, R.; Borrelli, C.; Forcina, A. Life cycle assessment of recycled concretes: A case study in southern Italy. Sci. Total Environ. 2018, 615, 1506-1517. [CrossRef] [PubMed]

16. Hossain, M.U.; Poon, C.S.; Dong, Y.H.; Lo, I.M.C.; Cheng, J.C.P. Development of social sustainability assessment method and a comparative case study on assessing recycled construction materials. Int. J. Life Cycle Assess. 2018, 23, 1654-1674. [CrossRef]

17. Marinković, S.B.; Ignjatović, I.; Radonjanin, V. Handbook of Recycled Concrete and Demolition Waste (Life-Cycle Assessment of Concrete with Recycled Aggregates); Woodhead Publishing Series in Civil and Structural Engineering; Woodhead Publishing: Cambridge, UK, 2013; pp. 569-604.

18. Rodríguez-Robles, D.; Van Den Heede, P.; De Belie, N. New Trends in Eco-Efficient and Recycled Concrete (Life Cycle Assessment Applied to Recycled Aggregate Concrete); Woodhead Publishing Series in Civil and Structural Engineering; Woodhead Publishing: Cambridge, UK, 2019; pp. 207-256.

19. Tošić, N.; Marinković, S.; Dašić, T.; Stanić, M. Multicriteria optimization of natural and recycled aggregate concrete for structural use. J. Clean. Prod. 2015, 87, 766-776. [CrossRef]

20. Wijayasundara, M.; Crawford, R.H.; Mendis, P. Comparative assessment of embodied energy of recycled aggregate concrete. J. Clean. Prod. 2017, 152, 406-419. [CrossRef] 
21. Cuenca-Moyano, G.M.; Zanni, S.; Bonoli, A.; Valverde-Palacios, I. Development of the life cycle inventory of masonry mortar made of natural and recycled aggregates. J. Clean. Prod. 2017, 140, 1272-1286. [CrossRef]

22. Taehyoung, K.; Sungho, T.; Seongjun, R. Assessment of the $\mathrm{CO}_{2}$ emission and cost reduction performance of a low-carbon-emission concrete mix design using an optimal mix design system. Renew. Sustain. Energy Rev. 2013, 25, 729-741.

23. Serres, N.; Braymand, S.; Feugeas, F. Environmental evaluation of concrete made from recycled concrete aggregate implementing life cycle assessment. J. Build. Eng. 2016, 5, 24-33. [CrossRef]

24. Shan, X.; Zhou, J.; Chang, V.; Yang, E.-H. Life cycle assessment of adoption of local recycled aggregates and green concrete in Singapore perspective. J. Clean. Prod. 2017, 164, 918-926. [CrossRef]

25. Colangelo, F.; Cioff, R. Mechanical properties and durability of mortar containing fine fraction of demolition wastes produced by selective demolition in South Italy. Compos. Part B 2017, 115, 43-50. [CrossRef]

26. Kim, T.H.; Tae, S.H. Proposal of Environmental Impact Assessment Method for Concrete in South Korea: An Application in LCA (Life Cycle Assessment). Int. J. Environ. Res. Public Health 2016, 13, 1074. [CrossRef] [PubMed]

27. Kim, T.H.; Tae, S.H.; Suk, S.J.; George, F.; Yang, K.H. An Optimization System for Concrete Life Cycle Cost and Related $\mathrm{CO}_{2}$ Emissions. Sustainability 2016, 8, 361. [CrossRef]

28. Ministry of Land, Transport and Maritime Affairs of the Korean government. National D/B for Environmental Information of Building Products; Ministry of Land, Transport and Maritime Affairs of the Korean Government: Sejong, Korea, 2008.

29. Korea Environmental Industry and Technology Institute. National Life Cycle Index Database Information Network. Available online: http:/ / www.edp.or.kr (accessed on 31 October 2018).

30. IPCC Guidelines for National Greenhouse Gas Inventories. Available online: http:/ / www.ipccnggip.iges.or. jp/public/2006gl/ (accessed on 31 October 2018).

31. Guinee, J.B. Development of a Methodology for the Environmental Life Cycle Assessment of Products: with a Case Study on Margarines. Ph.D. Thesis, Leiden University, Leiden, The Netherlands, 1995.

32. Heijungs, R.; Guinée, J.B.; Huppes, G.; Lamkreijer, R.M.; Udo de Haes, H.A.; Wegener Sleeswijk, A.; Ansems, A.M.M.; Eggels, P.G.; van Duin, R.; de Goede, H.P. Environmental Life Cycle Assessment of Products. Guide (Part1) and Background (Part 2); CML Leiden University: Leiden, The Netherlands, 1992.

33. World Metrological Organization (WMO). Scientific Assessment of Ozone Depletion: Global Ozone Research and Monitoring Project; WHO: Geneva, Switzerland, 1991; p. 25.

34. Derwent, R.G.; Jenkin, M.E.; Saunders, S.M.; Piling, M.J. Photochemical ozone creation potentials for organic compounds in Northwest Europe calculated with a master chemical mechanism. Atmos. Environ. 1998, 32, 2429-2441. [CrossRef]

35. Jenkin, M.; Hayman, G. Photochemical Ozone Creation Potentials for oxygenated volatile organic compounds: Sensitivity to variation is in kinetic and mechanistic parameters. Atmos. Environ. 1999, 33, 1275-1293. [CrossRef]

36. Jung, J.S.; Lee, J.S.; An, Y.J.; Lee, K.H.; Bae, K.S.; Jun, M.H. Analysis of Emission of Carbon Dioxide from Recycling of Waste Concrete. Archit. Inst. Korea 2008, 24, 109-116.

37. Kim, T.H.; Tae, S.H.; Chae, C.U.; Choi, W.Y. The Environmental Impact and Cost Analysis of Concrete Mixing Blast Furnace Slag Containing Titanium Gypsum and Sludge in South Korea. Sustainability 2016, 8, 502. [CrossRef]

38. Lee, D.H.; Jun, M.H.; Bae, K.S. Correlation between density and absorption of domestic recycled aggregate. Korean Recycl. Constr. Res. Inst. 2011, 11, 95-96.

39. Kim, T.H.; Tae, S.H.; Chae, C.U. Analysis of Environmental Impact for Concrete Using LCA by Varying the Recycling Components, the Compressive Strength and the Admixture. Sustainability 2016, 8, 389. [CrossRef]

(C) 2019 by the authors. Licensee MDPI, Basel, Switzerland. This article is an open access article distributed under the terms and conditions of the Creative Commons Attribution (CC BY) license (http://creativecommons.org/licenses/by/4.0/). 